\title{
Dissect Fraud of Planning and Bidding for Procurement of Goods and Service
}

\author{
Rohmaniyah*, Dr. Siti Musyarofah, Dr. Tarjo \\ Economy and business faculty of Trunojoyo University,St. Raya Telang PO.BOX 2 Kamal, Bangkalan, Madura, \\ Indonesia
}

*Corresponding Author: Rohmaniyah, Economy and business faculty of Trunojoyo University, Madura, St. Raya Telang, PO.BOX 2 Kamal, Bangkalan, Madura, Indonesia

\begin{abstract}
Rohmaniyah, Dissect Fraud of Planning and Bidding for Procurement of Goods and Service. Guidance by Dr. Siti Musyarofah, SE., M.Si., Ak., CA and Dr. Tarjo, SE, M.Si., CFE.

This research examines fraud in planning and bidding for procurement of goods and services. Procurement of goods and services is a forum that bridges the progress of development in IndonesiaThis study intends to analyze fraud practices at the planning and bidding stages of procurement of goods and services. This study was conducted in PT X which is engaged in contracting. The method used in this study was qualitative methods with a case study approach. The research method used were observations and interviews with informants. Information on research was partners, auction committees, Head of Regional Device Organizations (OPD), Commitment Making Officers (PPK), and competitors. The results of the study showed that cooperation between partners and the government has occurred before auction planning. Political aspects and the closeness of committee and partners caused fraud in the planning and bidding of goods and services, and the unprofessional committee for the procurement of goods and services.
\end{abstract}

Keywords: Fraud, Planning, Bidding, Procurement of goods and services

\section{BACKGROUND OF STUDY}

Procurement of goods and services is one of the biggest contributors to corruption in the public financial sector in Indonesia based on the 2019 Corruption Eradication Corruption (KPK) annual report, the number of cases in procurement was 174 cases with a value of 957,3 billion state losses and a bribe value of 91,5 billion(KPK, 2019). Procurement of goods and services is often identified with is called fraud, both in the planning process, bidding, implementation and even reporting (Artantri et al., 2016). Based on the 2015 semester Corruption Watch (ICW) Index report, corruption in procurement of goods and services is a source of state financial leakage with embezzlement mode with 82 cases, misuse of the budget of 64 cases, abuse of authority of 60 cases, and mark up of 58 cases. (Matthew et al., 2013) stated that procurement is very vulnerable to the risk of fraud and corruption both in the private sector and government by bribery to contracting officials. In the procurement of fraud can be started from procurement officials or vice versa from the provider of procurement of goods and services. Procurement of goods and services is one source of budget leakage.

Fraud is an unlawful act commited on purpose for a specific purpose by parties inside or outside the organization to gainindividual or group benefits (Association of Certified Fraud Examiners, 2016).(National Fraud Authority, 2012) suggests fraud in the procurement of goods and services is intentional fraud intended to influence each stage of procurement to obtain financial benefits or cause losses that can be done by external and internal organizations. Fraud includes a variety of irregularities and illegal actions that are characterized by intentional fraud (Matthew et al., 2013). Factor in the occurrence of fraud due to low internal control (Tuanakotta, 2010).

The system procurement of goods and services is considered to be the main source of budget leakage, where the use of conventional systems enables corruption and collusion which results in a large deterioration in public services (Nugroho, 2015). The system failure indicates there is a conflict of interest within the organization. In the conventional method of procuring goods and services 
interested parties will often meet and there is an opportunity to commit fraud that benefits certain parties.

The weakness of the system of procurement conventional goods and services is a challenge for the government to create a system that can reduce occurrence of fraud in the procurement of goods and services. Through the Government Goods and Services Procurement Policy Agency (LKPP) number 54 of 2010 (Presiden \& Indonesia, 2010), the government made a solution to create goods and services procurement activities that can be carried out professionally, transparently, and accountably so they are free from corruption. (Neupane et al., 2014) showthat developing and developed countries have implemented e-procurement to increase transparency and accountability as an anti-corruption factor in the e-procurement system and have an impact on reducing corruption in government procurement of goods and services.

The process of procuring goods and services starts from planning, offering, implementing and reporting. The indicated procurement of goods and services can occur starting from the auction planning process, namely before the auction is announced by the auction committee. Interested parties and having proximity to the procurement of goods and services will try to influence the decisions of procurement planning. Fraud procurement of goods and services also occurs in auction offers with the aim of winning tenders.

The Research related to e-procurement has been carried out by several researchers, namely (Mahmood, 2010), (Udoyono, 2012), (Messah et al., 2013), (Novitaningrum, 2014), (Faisol et al., 2014), (Neupane et al., 2014),(Arfanti, 2014),(Mantzaris, 2014),(Ishak \& Said, 2015). Then the research examining related to prevention of fraud the topic of study for The role of E-Procurement in Preventing Fraud in the Procurement of Goods/Services by local Government on the island Lombok (Artantri et al., 2016). However, e-procurement research related to dissecting procurement frauds starting from planning and offering is still not widely done. Therefore the researcher seeks to examine and examine fraud in the planning and bidding of procurement of goods and services.

PT $X$ is a private contracting company engaged in road construction, irrigation networks, culverts, bridge construction, and erection. Phenomenon that occurs in PT X, there are indications of fraud in the planning process and bidding where between partners cooperating with related agencies begins before the tender is auctioned through the Electronic Procurement Agency (LPSE). At the time of PT X's auction planning, the partners had begun to approach with the aim of knowing the methods that would be used during implementation in the field. The auction offer will be made through Electronic Procurement Agency (LPSE) but because there has been a previous approach with the auction committee PT X it will be easier to find out the auction requirements compared to other partners, in addition to uploading the bid documents there is an agreement with the auction committee so that the LPSE system often has problems intentional bidding shortened.

Researchers assume that this research is important to do with consideration to find out the problems, understanding, and facts of what happened in the planning and bidding process. That was done whether in the implementation of the planning and bidding the auction is accordance with existing procedures and regulations.

Based on the background above, the formulation of problem in this study is how to practice fraud that occurs at the stage of auction planning and auction bidding. This study aims to analyze the practice of fraud that occurs at the stage of auction planning and auction bidding.

\section{METHOD}

The method used in this study was qualitative methods. Qualitative research is research that intends to understand the phenomenon of what is experienced by research subjects such as behavior, perceptions, motivations, actions, etc by means of descriptions in the form of words in a specific natural context (Moleong, 2010). The data used in this study is primary data obtained from interviews. The object of this research was carried out at "PT X" which is a private company engaged in the contracting sector.

The research method used were observation, unstructured interviews so the informants are more flexible in giving information related to the things asked in the study. Bidding documents such as completeness of core personnel data, company permits, receipt of equipment purchases, and certification for core personnel as supporting data in data analysis. 
The technique of collecting data in qualitative research is to give meaning data by sorting it and categorizing it into a part based on certain classifications so the conclusions are drawn on the formulation of the problem under study. Data triangulation data grouping, analysis of documents and data, and drawing conclusions from the results of the analysis are data analysis techniques in this study.

\section{RESULT AND DISCUSSION}

\subsection{Auction Planning Stage}

Planning is a process of determining what you want to achieve and determining the stages neededto achieve them(Taufiqurokhman, 2008). In general in planning about the plan of images, details and specifications. There are several stages that must be passed in the tender planning phase. Planning is the stage for preparing pre-design, site plans and organizational arrangements for rooms, completing detailed drawings, construction calculations, costs, technical and administrative specifications and completing all auction documents

\subsubsection{Approaches Before Auction Planning}

Fraud does not only occur at the procurement stage, but occurs at the planning stage. The office will hold a plan to select the selected CV planner who will later do a plan regarding a tenderThe partner approach to planning consultants has become commonplace in the world of contractors and for other partners this method is legitimate. According to (O'Leary, 2012)that the design of cooperation by the parties concerned must go through stages, cooperation and of course by adhering to the same vision for the interests of the client, and the client himself must have coordination with the company by collaborating all aspects of support who can support the implementation of the procurement of goods and services.

The approach in an activity according to the Head of Regional Device Organization (OPD) is an ordinary thing but remains within the limits of reasonableness and does not affect the decision of the consultant planner in making design, budgeting for auction and scheduling costs.

\section{"Yes actually where-where it is, surely the approach is there, but still in a reasonable stage the intention is not to influence the decision of the consultant planner as the one who designs and tracks the work" (Source: Head of Regional Device Organization (OPD)}

From the results of the interview above, it was confirmed that fraud at the auction had been planned before the auction announcement was issued at LPSE. In the world of procuring lobbying goods and services and approaching it is considered normal and even allowed as long as it is not discovered. Partners and planner consultants have begun to "flirt" to smooth out the intention of the partners to provide a description of the plan that will be designed by the planning consultant such as the location of the work with the partner's objectives to prepare work methods before the announcement of the tender auction at LPSE.

So the partners have started to take part in planning to find out the location of work so that other partners who will take part in the auction find it difficult to develop work methods. The researcher translated that in the planning there had been a procurement that was directed by one of the partners that was indeed indicated to match the tender.

At this stage the parties involved are PT X as the company that was planned to win in auction to approach the consulting consultant. In addition to PT X, the party involved in the consultant planner, PT X tried to approach and influence the planning consultant to be given information about the work location in order to facilitate the making of work methods of a job and the method was made before the opening of the auction in the LPSE system.

\subsubsection{Lubrication Before Opening the Auction}

Collaboration here is not only limited to approaching but already has a high commitment between the two parties with a "lubricant" in advance to the consultant planner. The auction committee and the relevant regional officials will be bribed with lubricant payments in advance by partners. Provision lubricant payments to influence authority which is carried out in secret and doesn't have proof of the 
transaction provided by the beneficiary of the lubricant paymentto the provider of the lubricant payment. The following is a statement from the director of PT X.

"This is the name of the fee eh is not the fee, yes, like the intermediary, so (money) information for consultant planners so we can information on the minimum planning regarding work methods and back to our company is good. Usually we are also directed about what a good design is with the purpose of winning the tender / auction."

Based on the results of interviews with related parties before there were facilitators to facilitate the interests of PT X and the benefits for certain parties an approach was taken to all parties. The money to expedite this interest was given in advance before the planning auction and actually the official also knew that the project to be auctioned would be won by one of the companies that had already committed at the outset. From the PPK statement there is indeed a facilitation payment, there are only certain parties who are brave and carried out clandestinely.

Fraud at the stage of auction planning we can map it into several parts, namelyApproach or lobbying to the Planning Consultant who has been declared victorious in the planning auction and to the Commitment Making Officer (PPK), Giving "facilitation payments" so that the procurement can be directed tender, and planning before the auction is announced with the aim of being able to master and make the work methods and images as good as possible.

\subsection{Fraud Auction Offering}

The bidding strategy for a company depends on the company's goals, including maximizing profits. The characteristics of contracts in the construction industry are characterized by increasing competition, not high profit margins and high risk of failure.More companies engaged in construction the competition between companies with one another. With the competition, the company inevitably must have a strategy to defeat other companies or in other words win the auction of the project.The bidding document is a document that will be used as a reference and information for construction service providers or contractors to bid or offer a construction project.

Indications of fraud do not only occur during planning. At the bidding stage, fraud occurs a lot between the auction committee and partners, partners with the OPD leadership. The modes of fraud are different.

Fraud at this stage of the auction made other partners suffer because one of the partners used a fraudulent method to win the tender. One of the frauds in the auction bidding stage is usually the committee will provide information about the auction requirements that must be prepared in advance to one of the partners who was appointed to win the auction.

"Our auction requirements usually already know preparing ahead of time because we already know before the opening of the auction. That information was obtained from the auction committee which was indeed by the company in the lobby to provide information about the requirements. "

The above statement has confirmed that PT X has prepared all the requirements that will be launched at the opening of the auction. So before the auction was announced, PT X had thought about how the government auction could be won by PT X.

The suppliers of goods and services full access to information on the procurement of goods and services in XYZ district. The presence of insiders involving the auction committee who has the authority and role in terms of bidding does not cover the possibility of fraud can be carried out in the interest of the group.In this case the e-procurement application is still not effective in preventing the meeting between the auction committee and the partner as prospective winner of the auction. The existence of a system does not have a major influence on reducing fraud.

\subsubsection{Injustice of the Auction Committee}

Fraud was conducted by the auction committee at the time of bidding because the committee felt they had a partner who was made a winnerin the offer. In addition, the auction committee is also committed to the partners who become the champion. The committee seems to side with one of the partners because there is indeed a factor in the closeness and conditioning of the auction committee. 
"Yes, it is normal for anyone who approaches the auction requirements to be given a picture that does not fit in detail, so the terms and conditions used in the auction will be discussed later."

The auction committee actually knows the list of core personnel as evidenced by certificates in the form of Expertise Certificates (SKA) and Work Skills Certificates (SKT), not all of which are included in the list of core personnel working at PT X even though there are gaps from partners who have commitments with the committee because they have committed to all the auction committees. Expert energy work in the service and construction sector are required to have Expertise Certificate (SKA) and work Skills Certificate (SKT) issued by the Construction Service Development Institute (LPJK) with SKA and SKT expert energy have been recognized as having expertise,competence, and job skills in the construction service sector. ${ }^{1}$

From the interview presentation, the parties involved were the auction committee and the chairman of the auction committee, the Director of PT X and the bidding section. The way to smooth out the action was the committee notifying the auction requirements in advance to the partner who was the champion. Fraud by prioritizing one partner is very detrimental to the other partners because the other partners feel there is no fraud but behind the scenes the committee and partners can still meet.

\subsubsection{Fee Before the Bidding Stage}

Conditioning has been carried out long before the auction was announced at LPSE, usually in the previous six months the partners had lobbied and started conditioning from the head of the agency, PPK and the auction committee. The provision of fees has become commonplace among associates as a sign of initial commitment with those invited to cooperate. As long as there is an opportunity to condition and approach it all, it will be done by partners to make it easier for partners who want to win to get the tender. The following is a statement from the Director of PT X regarding fees:

"The fee was given before the offer and far away that day. For example, when the auction before it was launched 6 months before we had approached the auction committee, then the first political aspect was to be the head of the region. Yes, for example, we do not carry one of the candidates who only has projects that are of small value. The fee is not only the auction office, but also the head of his office is given and certainly the head of his office is bigger. If the auction committee is between the committee chairman and its members, it is different but they will later divide it. The transfer method is not transferred but in cash."

The prize itself means giving something to someone with the intention of glorifying or giving an award to him. Another meaning of the gift is the provision of money, goods, services and so on which is done without any back compensation even though it does not rule out the possibility of the gift giver expecting a return. The role of gifts can increase social closeness in human relations.

From the above review, it is possible that the gift is loaded with interests because giving gifts can create a close relationship. Unlike sadaqah, which is a gift of someone to others sincerely or voluntarily without the limitation of time and amount. Alms given by someone without any pressure from other parties. A person can give alms whenever he wants.

Meanwhile gratification means giving in the broad sense in the form of additional costs (fees) in the form of money, goods, services or other facilities. This gratification can lead to bribery if there is a promise behind the gratification. Whatever term is used, whether it's a gift, charity or gratification, the researcher summarizes it with the term "Thank you". This thank you made by PT X is a common thing done by all other partners in XYZ District with the aim of helping smooth work

Fee was indeed given before the auction was launched to facilitate the partners themselves admitted that there was indeed some kind of fee but the auction committee and the OPD leadership still did not say that their fee considered the money thanks after winning.

\subsubsection{Political Aspects / Reply to Services}

\footnotetext{
${ }^{1}$ Abdul Rahman Ma’mun dkk. 2014. Indonesia Bebas Uang Pelicin. Jakarta:Transparency International Indonesia. Hal.3 diakses darihttps://www.pengadaan.web.id/2019/05/daftar-kode-sub-bidang-ska-dan-skt.html
} 
Politics is indeed not far from everyday human life even in the procurement of goods and services and there must be consequences that must be paid behind as there is a reward for what was done first.Politics is closely related to public decision-making processes, how to use these authorities and what is the purpose of an agreed decision. Conflict and cooperation in a public decision-making process are an inseparable unit as part of the process of interaction between interests. The aspirations and interests of each group and individuals in society are not always the same, but are different even in many ways contrary to each other (Surbakti, 2016).

\section{"Yes, it is usual in politics that there must be reciprocity or that there are no free services if the project already belongs to this because indeed from the beginning they might already have a commitment."}

The political aspect here is the remuneration of the head of the region and the head of the official department that was once carried in the victory by donating in funding. In nominating officials, they will seek donors to win their election when the candidate who has been promoted has won so easily the partners who take part in winning him easily ask. The project will be rationed by officials for its supporters, especially for the bearers who pour the most funds will get a project ration which is of great value. It is not uncommon for officials or regional heads to often be governed and influenced by one partner who has closeness.

In politics, supporters of opposing parties who previously competed in political contestants tend not to be given or given the opportunity to win projects whose value is large, usually only get a small project because there are already separate jatang. The parties involved in this farud are the Director of PT X and the official.

\subsubsection{Flag Rental and Collusion of Company Ownership}

Borrowing a flag or name of another company-owned business entity in the auction process is a business entity that uses the name of another company to take part in the auction process for the procurement of goods and services acting for and on behalf of the borrowed company. If the business entity is appointed as the winner in the process of procurement of goods and services, the implementation of the work is not by the business entity that becomes the winner, but rather the business entity that has borrowed the name of the business entity. This situation has brought losses to the government or owners of business entities.

Collusion of ownership of a business entity or company in the procurement of goods and services is an ordinary thing where one person has many business entities, but over others. The aim is to make the governing body a lot, namely as a comparison later in bidding in addition to being able to bid on many projects.

Opportunity is a situation that allows a person to commit fraud, a situation that is considered safe by fraud perpetrators (fraudsters) to act with the assumption that their actions will not be discovered. Opportunities usually arise because of an ineffective system, lack of controls to prevent or detect fraud inability to assess the quality of a performance, failure to discipline themselves, incompetence / ignorance of victims of fraud due to lack of information (Albrecht et al., 2012). Someone who is good at reading situations will look for loopholes in a policy or other regulation. He sought weaknesses from a rule to be exploited or taken advantage of. He can also take advantage of the lack of effective supervision. Therefore, one way to minimize fraud is to create a good control system.

(Becker et al., 2006) explain that opportunities have a positive effect on fraud behavior. The greater the opportunity available for someone to commit fraud, the greater the likelihood that the person will commit fraud. In particularthe study states that the environment has a contribution where norms and values also contribute to facilitating fraud.

Flag rental is done if all the business entities owned by them have been included in all auctions and winning partners will usually borrow flags belonging to other companies. Collusion of ownership of this business entity is a partner strategy to get many projects. The name of the business entity is what is called the son-in-law, close friend, and family even though the place of operation is one place.

\section{Conclusion}


Based on the discussion and interview with the informant about fraud that occurred in the auction planning and auction bidding it can be concluded that:

Associates have begun to take part in planning to find out the location of work so that other partners who will take part in the auction find it difficult to develop work methods. The researcher translated that in the planning there had been a procurement that was directed by one of the partners that was indeed indicated to match the tender. Approach or lobbying to the Planning Consultant who has been declared victorious in the planning auction Giving "facilitation payment" so that the procurement can be directed to make the working method easier because it already knows the location of the job first.

The provision of fees has become commonplace among associates as a sign of initial commitment with those invited to cooperate.

\subsection{Suggestion}

Based on the results of the discussion and conclusion, the suggestion that the author can give in this study is that the Government must improve the e-procurement system to reduce face-to-face meetings between partners and the auction committee. Supervision carried out by supervisory consultants and Commitment Making Officers (PPK) to partners to be carried out in accordance with procedures and seriously. For partners, it is expected that they do not approach the service that can harm other competitors.

\section{REFERENCES}

[1] Albrecht, W. S., Albrecht, C. O., Albrecht, C. C., \& Zimbelman, M. F. (2012). Fraud Examination. SouthWestern Cengage Learning. https://doi.org/10.1017/CBO9781107415324.004

[2] Arfanti, M. A. C. (2014). Pelaksanaan Sistem E-Procurement Dalam Pengadaan Barang/Jasa Pemerintah Untuk Mencegah Terjadinya Persekongkolan Tender. Jurnal Universitas Brawijaya.

[3] Artantri, L. P. R. M., Handajani, L., \& Pituringsih, E. (2016). Peran E-Procurement Terhadap Pencegahan Fraud Pada Pengadaan Barang/Jasa Pemerintah Daerah Di Pulau Lombok. NeO Bis, 10(1), 16-32.

[4] Association of Certified Fraud Examiners, I. C. (2016). Survei fraud Indonesia 2016. ACFE Association of Certified Fraud Examiners.

[5] Becker, S., Fonseca-Becker, F., \& Schenck-Yglesias, C. (2006). Husbands' and wives' reports of women's decision-making power in Western Guatemala and their effects on preventive health behaviors. Social Science and Medicine, 62(9), 2313-2326. https://doi.org/10.1016/j.socscimed.2005.10.006

[6] Faisol, I. A., Tarjo, \& Musyarofah, S. (2014). Pengaruh Penerapan E-Procurement Terhadap Pencegahan Fraud Di Sektor Publik. JAFFA Oktober, 02(2), 71-90.

[7] Ishak, M. W., \& Said, J. (2015). Assessing The Role of Anti-Corruption Initiatives in Reducing Lobbyist Involvement In E-Procurement: A Case Study of Mardi. Procedia Economics and Finance, 31(15), 485494. https://doi.org/10.1016/s2212-5671(15)01182-x

[8] Mahmood, S. A. I. (2010). Public procurement and corruption in Bangladesh confronting the challenges and opportunities. Journal of Public Administration and Policy Research.

[9] Mantzaris, E. (2014). Public procurement, tendering and corruption: realities, challenges and tangible solutions. 7(2), 67-79.

[10] Matthew, K., Patrick, K., \& Denise, K. (2013). The effects of fraudulent procurement practices on public procurement performance. International Journal of Business and Behavioral Sciences, 3(1), 17-27.

[11] Messah, Y. A., Asmat, M. Y., \& Rizal, H. A. (2013). Kajian Persepsi Pelaku Jasa Konstruksi tentang Kegiatan Pengadaan Jasa Konstruksi Secara E-Procurement di Kota Kupang. Jurnal Teknik Sipil, II(1), $11-22$.

[12] Moleong, L. J. (2010). Meode Penelitian Kualitatif. Landasan Teori. https://doi.org/10.1017/CBO978110 7415324.004

[13] National Fraud Authority. (2012). Annual Fraud Indicator. Annual Fraud Indicator.

[14] Neupane, A., Soar, J., Vaidya, K., \& Yong, J. (2014). Willingness to adopt e-procurement to reduce corruption: Results of the PLS path modeling. Transforming Government: People, Process and Policy. https://doi.org/10.1108/TG-03-2014-0007

[15] Novitaningrum, B. D. (2014). Akuntabilitas dan Transparansi Pengadaan Barang dan Jasa Pemerintah Melalui Electronic Procurement ( Best Practice di Pemerintah Kota Surabaya). Kebijakan Dan Manajemen Publik, 2(1), 200-210. 
[16] Nugroho, R. (2015). Pengaruh Implementasi Sistem Pengadaan Secara Elektrinik (E-Procurement) Terhadap Fraud Pengadaan Barang/Jasa Pemerintah (Studi Pada Satuan Kerja Perangkat Daerah Kabupaten Magetan). None, 3(11), 1905-1911.

[17] O’Leary, T. (2012). Decision-making in organisations. In Project Governance: Getting Investments Right. https://doi.org/10.1057/9781137274618

[18] PRESIDEN, \& INDONESIA, R. (2010). Peraturan Presiden Republik Indonesia Nomor 54 Tahun 2010. https://jdih.lkpp.go.id/regulation/964/peraturan-presiden-nomor-54-tahun-2010

[19] Surbakti, R. (2016). Perekayasaan sistem pemilu untuk pembangunan tata politik demokratis. Kemitraan Partnership.

[20] Taufiqurokhman. (2008). Konsep dan Kajian Ilmu Perencanaan. 1-98.

[21] Tuanakotta, T. M. (2010). Akuntansi Forensik \& Audit Investigatif. In Edisi 4. https://doi.org/10.1016/j. clay.2015.06.031

[22] Udoyono, K. (2012). E-PROCUREMENT DALAM PENGADAAN BARANG DAN JASA UNTUK MEWUJUDKAN AKUNTABILITAS DI KOTA YOGYAKARTA. Journal of Government and Politics. https://doi.org/10.18196/jgp.2012.0008

\section{AUTHOR'S BIOGRAPHIES}

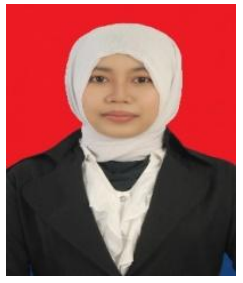

ROHMANIYAH, SAMPANG, 28-11-1993, 082234910545. I am currently working as a lecturer at Madura university.

Citation: Rohmaniyah, Dr. Siti Musyarofah, Dr. Tarjo. "Dissect Fraud of Planning and Bidding for Procurement of Goods and Service" International Journal of Managerial Studies and Research (IJMSR), vol 8, no. 11, 2020, pp. 26-33. doi: https://doi.org/10.20431/2349-0349.0811004.

Copyright: (C) 2020 Authors. This is an open-access article distributed under the terms of the Creative Commons Attribution License, which permits unrestricted use, distribution, and reproduction in any medium, provided the original author and source are credited. 